\title{
Caseworker Prejudice: Exploring Secondary Non-Take-Up from Below Among Latino Immigrants in Madrid, London, and New York City
}

\author{
Marie Mallet* and Edwin Garcia**
}

\begin{abstract}
This article investigates the understudied phenomenon of secondary non-take-up (NTU) among Latino immigrants in Madrid, London, and New York City from their own perspective. It examines the reasons behind secondary NTU across the three sites and examines the relevance of type of welfare state in which they live. The findings of this paper suggest that secondary NTU is prevalent in these three sites. It identifies prejudice from social workers as the leading cause of secondary NTU among Latino immigrants.

Keywords: Non-take-up (NTU), immigration, welfare state, discrimination, public policies

\section{Les préjudices des travailleurs sociaux: exploration du non-recours secondaire chez les immigrants latino-américains à Madrid, Londres et New York}

Résumé: Cet article examine l'aspect sous-étudié du non-recours secondaire chez les immigrants latinos à Madrid, Londres et New York. Il analyse leurs raisons dans les trois sites et s'interroge sur le rôle de l'État providence dans lequel ils vivent. Les résultats de cet article suggèrent que le non-recours secondaire est prévalent dans ces trois sites. Il identifie les préjugés des travailleurs sociaux comme la principale cause de non-recours secondaire parmi les immigrants latinos.

Mots-clés: Non-recours, immigration, état providence, discrimination, politiques publiques

\section{Voreingenommenheit von Sozialarbeitern: Eine Analyse des sekundären Nicht-Be- zugs von lateinamerikanischen Einwanderern in Madrid, London und New York}

Zusammenfassung: Dieser Artikel untersucht den bis dato wenig beachteten Aspekt des sekundären Rückgriffs unter lateinamerikanischen Einwanderern in Madrid, London und New York. Er analysiert die Gründe hierfür an den drei Standorten und hinterfragt die Rolle der unterschiedlichen Wohlfahrtsstaaten. Die Ergebnisse dieses Artikels legen nahe, dass an diesen drei Standorten sekundäre Rückgriffsmöglichkeiten vorherrschen. Die Voreingenommenheit der Sozialarbeiter wird als Hauptursache für den sekundären Rückgriff unter LatinoEinwanderern identifiziert.

Schlüsselwörter: Nicht-Bezug, Einwanderung, Wohlfahrtsstaat, Diskriminierung, öffentliche Politik

Centre on Migration, Policy and Society (COMPAS), University of Oxford, UK-OX2 6QS Oxford, marie.mallet-garcia@compas.ox.a.uk

** Université Sorbonne Nouvelle Paris III, F-75005 Paris, edwin-garcia@sorbonne-nouvelle.fr 
The non-take up (NTU) of social benefits is a widespread phenomenon in Western welfare states (Warin 2014; Eurofund 2015). Social benefits are intended to provide assistance to individuals in precarious financial situations and NTU is a challenge for policymakers, administrators, and stakeholders, as it may represent a failure in the policy design or its implementation (Mazet 2014). It further increases poverty and social inequalities in society by distorting the intended effects of redistribution policies (Bargain et al. 2012) and reduces the capacity to anticipate social outcomes and financial costs of policy reforms (Fuchs et al. 2020). While all industrialized countries provide basic safety nets to protect vulnerable individuals from falling below a certain level of economic well-being (Kayser and Frick 2000), the extent of this safety net and its coverage vary greatly across them. Additionally, the specific migration policies of each country further affects the eligibility of immigrants, whose social rights are greatly dependent on the entry category associated with their legal status (Sainsbury 2006).

The literature distinguishes between two types of NTU: primary NTU, which describes a situation when individuals do not apply for services for which they are eligible, and secondary NTU, which occurs when people who are eligible for social services are turned away by the administration (van Oorschot 1991). This paper focuses on the understudied aspect of secondary NTU among immigrants. The aim of this paper is to provide a better understanding of the factors that contribute to the NTU of social benefits by focusing on Latino immigrants' own perceptions for NTU in three cities located in different welfare states: Madrid, Spain, London, United Kingdom, and New York City, United States. It investigates whether the reasons for NTU vary across the three sites and examines the relevance of type of welfare state in which they live. It lays the groundwork for future studies in the field of immigrant integration through social services, by offering a method for a comparative analysis.

The findings of this paper suggest that secondary NTU is significant in these three cities and differs slightly depending on the type of welfare state in which Latino immigrants reside. This research focuses on what the analysis identified as the leading cause of secondary NTU among Latino immigrants in these three sites, that is prejudice from social providers. It brings to light 3 different causes: prejudice due to classism, prejudice against immigrants, and prejudice caused by ethno-racial reasons. These factors seem to be exacerbated by the co-ethnic concordance between social workers and beneficiaries. Additionally, while an analysis of the interviews found these three factors causing prejudice present in all sites, the leading reasons for NTU varied slightly across the cities. In the New York City, Latino immigrants' secondary NTU is mainly associated with social class, as caseworkers seem prejudiced against people who use public benefits. In London, Latino immigrants' secondary 
NTU was mainly linked to migration status, with immigrants perceived as abusing a generous welfare state. In Madrid, the most prevalent reason behind secondary NTU related to ethno-racial considerations.

\section{Background and Literature}

\subsection{Overview of the Types of NTU}

The NTU of social benefits refers to a phenomenon whereby individuals or households do not receive the social benefits for which they are eligible (Mazet 2014). The literature largely emphasizes primary NTU (van Oorschot 1996) and the reasons proposed to explain the phenomenon predominately revolve around the adoption cost-benefit analyses, which traditionally prevail in the economics literature and assume individuals to be rational beings who can objectively ascertain the trade-offs between take up and NTU (Bargain et al. 2012; Warin 2014). Existing research has identified the following costs as contributing to non-take up: (1) Information costs - which include the complexity of the program, such as its eligibility requirements (2) Process costs - such as the cost of having to apply (in time and money) and (3) Outcome costs - referring to the stigma attached to the program. Expanding on these categories, Philippe Warin (2008) also argued that some individuals chose not to take up benefits by lack of interest. This classification is useful to assess the causes of NTU, and studies showed that process costs play a particularly important role for take up (Currie 2004) while information costs are less relevant in the NTU decision (Bruckmeier and Wiemers 2017).

While these studies provide insight into NTU, they emphasize the responsibility borne by the potential beneficiaries, who become responsible for not claiming benefits they are entitled to receive (van Oorschot 1996), while downplaying the role that the administration, local-level bureaucrats and service providers can play in NTU. Some studies have addressed this limitation by investigating the role played by other actors (van Oorschot 1995), suggesting that NTU might be better analyzed as "Non-give-out" (Eurofund 2015). They have showed that at the organizational levels, complicated procedures and heavy bureaucracy may lead to NTU, as it increases the risk of errors and mistakes on the part of the administration (Brodkin and Majmundar 2010). Building on the work of Lipsky (1980), which showed that public service workers wield considerable discretion in the day-to-day implementation of public programs, recent studies have showed that these discretionary powers may negatively impact service delivery and NTU (Jessen and Tufte 2014). It reveals for instance that when they are overworked, social service providers may choose to prioritize or ration benefits. The literature in this area primarily focuses on the perspective of social providers (Weinberg 2010). However, there is a need to further examine (1) how recipients perceive their own interactions with social 
service providers and (2) how they perceive the influence of the discretionary power conferred upon administrators to implement policies. This paper proposes to do so by analyzing the interactions between service providers and immigrant beneficiaries "from below", and how it affects their access to and take-up of social benefits.

\subsection{Immigrant Eligibility across Welfare States}

While there is an extensive literature on NTU among native populations, less research has been conducted on immigrant NTU (Hooijer and Picot 2015). NTU is important for immigrants as it may hamper their integration and increase their risk of poverty (Dragos et al. 2010; Finn and Goodship 2014). Immigrants' access to public benefits is often complexified by the type of welfare state they live in, which plays a significant role in their secondary NTU. Migration and the rapid demographic changes it brings about are transforming receiving welfare countries, leading to intense debates over immigration policies. The contention that immigrants should not benefit from social services has led to diverging policies, some of which aim to restrict the access of immigrants to services in health care, education, and social aid such as housing assistance (Porter 2006). Laws designed to deter immigrants from using social services have been passed in multiple welfare countries (Sainsbury 2012). This tightening of policies also affects immigrants with valid residence permits - both temporary and permanent - who meet all relevant eligibility criteria for accessing welfare benefits and causes them to experience substantial variation in welfare rights compared to citizens (Römer 2017). There are two main factors causing variation in welfare rights and subsequent take-up of benefits for immigrants: First, the type of welfare state in which immigrants reside affects the policies in place in these receiving countries (Römer 2017). The eligibility criteria differ across welfare states: while some countries are more inclusive, others restrict access to narrower categories of individuals. In his seminal work, Esping-Andersen (1990) classified welfare states into three main categories: (1) liberal regimes, characterized by low state intervention; (2) conservative regimes, which provide more generous benefits based upon principle of insurance contribution and (3) social-democratic regimes, offering universal benefits at more generous levels. While this classification has since been further complexified (Ebbinghaus 2012), it remains a strong basis on which we build our analysis.

Among the countries studied in this article, both the United States and the United Kingdom are categorized in the literature as liberal welfare states (EspingAndersen 1990; Isakjee 2017). However, they differ in terms of their incorporation regime of immigrants, with the United States being a comparatively inclusive republican system, albeit driven by private initiatives, while the United Kingdom can be characterized as a postcolonial and rather exclusive regime for migrants, despite having one of the largest healthcare system in the world (Grosios et al. 2010; Sainsbury 2012). Indeed, the United Kingdom's universal and generous post-war 
social policies have progressively shifted towards the increased privatization of social benefits and reduced immigrants' access to benefits for which they used to be eligible (Sainsbury 2012). Additionally, the UK's shift towards a digitized single system of social assistance (Harris 2020) may disproportionately negatively affect immigrants (Blix 2018), who may face barriers to digital access or be less prepared to navigate the online platforms. In the United States, recent restrictive policies have also been implemented to prevent immigrants from accessing social benefits. The Inadmissibility on Public Charge Grounds (also knowns as the Public Charge rule) was implemented on February 24, 2020 and it enables the federal government to refuse entry to new immigrants or refuse to extend or adjust the legal status of immigrants already on American soil if they have previously accessed, or are deemed likely to rely in future, certain forms of public benefits (USCIS 2018). By contrast, Spain, a relatively new welfare state, is sometimes considered as a Mediterranean (or Latin) welfare state or a continental welfare state (Esping-Andersen 1990). Similarly to the United States and the United Kingdom, recent reforms such as the 2012 reform of social services now excludes undocumented immigrants from accessing most social services (Moreno Fuentes and Bruquetas 2011), stripping them of any claim to benefit from many of the social rights to which they were previously entitled (Petropoulos et al. 2019).

Second, the variation in welfare rights for immigrants is also due to the local implementation of policies, particularly the degree of discretionary powers conferred upon local actors and street level bureaucrats. Indeed, in addition to these restrictive eligibility criteria, immigrants face intangible obstacles, such as suspicion and fear, when trying to gain access to social services (Scheibelhofer and Holzinger 2018). Previous research has highlighted the importance of social workers in the lives of immigrants and the effects of power dynamics that may exist in these relationships (Bourgois and Schonberg 2009). Recent studies have inconsistent results: some suggest that immigrants are more likely to take up these benefits compared with native populations (Riphahn et al. 2013), while others suggest that immigrants tend to underutilize these services in comparison with their native-born counterparts (Bruckmeier and Wiemers 2017). However, they concur in showing that the vulnerable status of migrants, partly characterized by having fewer resources at their disposal, makes them uniquely in need of these services (Shi et al. 2008). Immigrants thus often rely on service providers to whom they come for material and, sometimes, moral support (Ayón 2015). Among studies focusing on immigrant interaction with social services, competing findings have emerged, notably on recommendations related to co-ethnic concordance. Although some studies stress the importance of shared cultural understanding and recommend increasing the number of co-ethnic social service providers to serve immigrant populations (Arendt and Karadas 2019), other studies highlight the negative outcomes of co-ethnic healthcare workers on immigrants and suggest that ethnic concordance often hindered rather than improved 
clinical communication, as co-ethnic staff were perceived to exaggerate their social distance from patients (Lo and Bahar 2013).

\subsection{Contribution of this Article}

To address the conflicting results in the literature and assess the direct impact that administrators may have on immigrants, we draw on the multi-level influence model developed by van Oorshot (1996), which showed that full explanation of NTU requires to take into consideration factors operating at the scheme, administration, and beneficiaries levels, as well as the behaviors of policy-makers, administrators and recipients. The initial model was adapted by Reijnders et al. $(2018,1372)$ who argued that NTU is rarely the result of a unique factor but rather is "a multi-dimensional phenomenon" that is caused by "an intricate interplay of different factors" including factors operating at the local welfare system level, organizational level, and individual level, as well as the behavior of organizational representatives and the lived experiences of individuals. We adopt the holistic approach described above to investigate the role of secondary NTU and focus particularly on one aspect of this model, the interpersonal interactions between social providers and their recipients, from the point of view of immigrant beneficiaries.

\section{Method}

\subsection{Design}

This study proposes a comparative analysis of the reasons for NTU in three large urban centers, London, Madrid, and New York City. The motivation behind this choice is due to four main reasons: First, these cities present significant variations regarding the type of welfare services available to immigrants and immigration policies. These policies have a substantial impact on how social services providers interact with the Latino public and how Latino immigrants experience this encounter. Second, these cities have a significant number of Latino immigrants, thereby enabling an international comparison (see below). Particularly, including London in the analysis allows to further contrast the experiences of Latino immigrants in Spain and the United States, as both countries have colonial ties with Latin America. Finally, this selection allows an analysis across language use. In Spain, the official language is Spanish, which might ease communication for Latino immigrants. However, even if Latino immigrants do not face strong language barriers in Spain, research shows that they may experience discrimination based on their accent and lexicon (MarMolinero 2002). In comparison, in the United States and the United Kingdom, English is the official language, but Spanish translation is often available partly due to the needs of the expanding Spanish-speaking populations. 
This analysis focuses on Latino immigrants, to enable a robust comparison across different receiving contexts, by keeping the immigrants' ethnic origin constant. Latinos are an appropriate immigrant group for studying NTU across these sites as they (1) are present in sufficient numbers across all three countries of interest, (2) are not of EU-origin, as very different social protection rights apply to EU migrants in the case of London and Madrid, and (3) have no diaspora that is substantially driven by refugee migration, as this would be linked to specific social service needs that are beyond the scope and interest of this particular project. From a global perspective, Latin America and the Caribbean are one of the main origin regions of international migration (United Nations 2017). Their distribution across receiving countries is uneven, however, with a higher proportion in the United States and Spain than in the United Kingdom. Of the three countries, the United States has the largest number of Latino immigrants. The latest figures estimate that there were 19.4 million foreign-born Latinos in the United States in 2015, representing 34.4\% of the nation's total population and making them the nation's largest ethnic or racial minority (U.S. Census Bureau 2015). Spain's recent demographic mutations transformed the country from a country of emigration to one of immigration (Arango et al. 2015), with about $40 \%$ of migrants coming from Latin America (Morales and Echazarra 2013). In the United Kingdom, the Latino population is growing rapidly (McIlwaine 2011). Even though it only constituted 186469 individuals in 2011, they were predominantly concentrated in London (McIlwaine 2015).

\subsection{Sample and Recruitment}

The interviews analyzed for this paper were conducted with 210 Latino immigrants between 2015 and 2018. They were drawn from a larger collection of 450 interviews that we have been conducting since 2011 to uncover the mechanisms at play in the integration processes of immigrants and their interactions with social services. The specific interviews selected for this article come from a selection of 78 among the 210 initial interviews, who met the following criteria: (1) the interviewees had been living legally in their city of residence for a period of at least 5 years and (2) they had applied for public assistance benefits and had their claims denied (e. g. they did not give up due to other reasons such as cost).

Recognizing that Latino immigrants are a heterogeneous group (Calderon 1992; Schiller et al. 2006; Mallet and Pinto-Coelho 2018), purposeful sampling was conducted to obtain a sample whose diversity resembles the overall demographic profile of immigrants in each of the three sites. This accounted for (1) the relative socio-economic position within the country and (2) the origin countries of the local Latino population. The sampling process aimed to reach a cross-section of Latino immigrants from North America, Central America, South America, and the Caribbean, by including Mexicans, Cubans, Salvadorans, Dominicans, Argentinians, Puerto Ricans and Colombians. Brazilians were not included in the sampling 
to ensure continuity in the language spoken. These sampling considerations are important because ethno-racial inequalities are an important source of stratification in the origin countries of Latinos (Telles et al. 2015). It should be noted that the salience of religious differences between Latinos and the mainstream populations in the receiving countries is not strong (see Reitz et al. 2017 for salience of religion), and so the focus of the sampling focused on other important factors that are more relevant to this immigrant group: legal status, social class, gender, and ethnicity.

The initial sample in each site was constructed through convenience sampling and building connections to the local Latino communities. We used exploratory ethnography to become immersed in the Latino communities in these three cities and to create multiple points of entry for respondent recruitment. We further recruited respondents by contacting the embassies of Latin American countries, community leaders, including as priests and community organizers, to facilitate access to the populations. Snowball sampling was then used to reach new respondents, and when sufficient community access had been developed, the project's purposeful sampling design was emphasized to maximize representativity among participants. This method resulted in a sample of respondents of different national origins and socio-economic statuses.

\subsection{Interview Format}

We conducted semi-structured interviews to gain an understanding of the subjective vision of the respondents regarding their integration into the host society. We used standardized questions to steer the interviews, ensuring consistency in addressing the relevant topics, while still leaving latitude for the in-depth exploration of issues relevant to each interviewee as well as other topics that the interviewees wished to explore. The interviewees were encouraged to expand on various aspects of their lives that they thought might be relevant to the study, even if it was not included in the initial interview guide. We were interested in capturing emergent aspects of the issue that we may not have otherwise considered. We provided respondents with a description of the project as well as my contact information, and informed consent was gathered. The respondents were compensated for their time through a gift card ( $\$ 30, £ 20$ or $25 €)$.

Most interviewees chose to answer in Spanish $(n=72)$, but some preferred to use English $(n=6)$. The average interview duration was one hour and 10 minutes. Interviews collected detailed histories of the respondents' migration experiences, their current living situation, their socio-economic profile, as well access to and use of social benefits. All but 15 of the interviewees allowed for our conversation to be recorded. We transcribed all the recorded interviews verbatim; for the other 15 , we took extensive notes that allowed me to reconstruct the conversation and wrote down long quotes from our discussions. 


\subsection{Data Analysis}

After transcribing the interviews, we conducted an initial round of coding based on the categories of the interview guide, which were not focused on NTU: (1) the socio-economic characteristics of the respondents, including their age, gender, marital situation, number of children, household composition, type of accommodation, description of neighborhood, language proficiency; (2) their immigration status: visa situation, reason for migrating, journey to host country, help received, previous contacts in destination country; (3) their current living conditions in their host country: employment status, profession, income, general financial situation, remittances; (4) social assistance programs: questions specific to their destination country, including which aid they have received, how they became aware of it and the reason why they sought aid; (5) their experiences with each of the services they used (both negative and positive, although the analysis focuses primarily on the negative side). We conducted a second round of coding to codify information that was not originally present in the initial codebook but emerged from the first round of coding, to uncover patterns and additional information related to their relations with social services and social service providers, such as co-ethnic concordance. ${ }^{1}$

\section{$4 \quad$ Results}

The qualitative analysis of the interviews reveals that secondary NTU represents a significant proportion of the reasons behind the non-use to social benefits. Among the initial sample of 210 Latino immigrants, 197 have tried to access various types of public benefits. Among these 197 individuals, 78 of them declared not benefiting from social services to which they believe to be eligible due to factors beyond their control. The analysis thus focuses on these 78 negative encounters between Latino immigrants and social service providers.

The analysis suggest that secondary NTU is prevalent in London, Madrid and New York City. The main contributor to secondary NTU among Latino immigrants is perceived prejudice from service providers (62 of the 78 respondents, of which 24 in London, 26 in Madrid and 28 in New York). These service providers were sometimes perceived as exercising their discretionary powers to prevent applicants from receiving benefits for which they qualify. Following an examination of the respondents' subjective understanding of their interactions with service providers, the explanations that led providers to exercise their discretionary powers to prevent access to benefits can be classified into three main categories: (1) prejudice against welfare recipients (e.g. classism), (2) prejudice against non-native beneficiaries and

1 Note: our results focus on immigrants' perception of their interactions with social workers, as we chose to focus on their point of view of migrants, as opposed to the point of view of the caseworkers. 
(3) prejudice based on beneficiaries ethno-racial characteristics. However, these categories are not mutually exclusive, and, more often than not, Latino immigrants experience discrimination based on several of these three main categories. They also differ from the outcome costs (e.g. stigma) identified earlier as a source of primary NTU because in each of these cases, the respondent exhausted - or thought they had - all avenue to appeal the decision and obtain the benefits to which they were eligible. Additionally, there are other possible explanations for secondary NTU among Latino immigrants that were not developed in this article because they were much less frequent - these include for instance the perceived incompetence of social workers as well as their lack of time.

\subsection{Prejudice against Welfare Recipients}

One of the main causes of secondary NTU (or the "non-give-out" of social benefits for which they were eligible), relates to perceived prejudice on the part of street-level bureaucrats and service providers against the very people they are meant to help. This is exemplified by $\mathrm{Ana}^{2}$, a Colombian immigrant who has lived in New York for over 15 years. She first entered the United States with a student visa, and after graduating from college, she obtained a job in a small marketing company. She was able to adjust her status and now holds a Permanent Resident Card (also called Green card). Following the 2008 crisis, she lost her job and in 2010, she gave birth to her daughter. She has been struggling since then to find another position. When we met in 2018, she was working as a free-lance translator, occasional Spanish tutor, and was considering enrolling in a master's program to become a schoolteacher. Ana lives with her husband, also a Colombian immigrant and legal permanent resident, and their 10-year-old daughter, in a one-bedroom apartment in East Harlem, New York. After her husband was injured at work and subsequently lost his job, the family struggled to make ends meet and Ana applied for food stamps (currently the Supplemental Nutrition Assistance Program, or SNAP). Here is how she remembers her encounter with the caseworker:

They want to make you feel worthless. It took a long time to see someone. (...) She [the social worker] looked annoyed that I was there. She said all I need to do was fill out some papers, that it can be done online without her. But we need the food stamps and the money right away, so I brought all my documents so that things can be a little faster (...) I told her that I knew my rights because a friend of mine went through it and got it [SNAP and TA]. She asked so many questions (...) She kept repeating that it was not right, that people who use benefits are weak, that they are like a disease. (...). I spent hours there and, in the end, she said that I was not eligible because

$\overline{2}$ All names have been changed to ensure confidentiality. 
I had assets and that I needed to get a job like everybody else. She was very rude, telling me to stop wasting people's time and to get a job ${ }^{3}$.

A few weeks later, when Ana collected food in a nearby food bank, she spoke with a social worker who told her that there must have been a mistake and encouraged her to re-apply online. Ana went to a public library where she filed an online application. She then received confirmation that she was eligible to receive benefits, as well as subsidies to help her pay her gas and electricity bills.

Ana's interaction with her caseworker are not unique to immigrants and may thus also affect natives who seek similar public benefits. The situation that Ana describes, and the attitude of the caseworker does not seem to be motivated by her ethnicity or her migration status, but rather by her socio-economic position in society. In the United States, research has demonstrated that classism, particularly institutional and interpersonal classism (Lott and Bullock 2007), leads to prejudice, stereotyping and discrimination and perpetuate the deprivation and low status of poor people (Smith 2010). The predominant culture in the United States emphasizes self-interest, independence and the belief in individual responsibility for achievement (Hammack et. al 2018). This was embodied by the latest welfare reforms such as the Personal Responsibility and Work Opportunity Reconciliation Act of 1996 (PRWORA) and the Public Charge Rule, which restricted welfare and fostered independence.

This was recurrent in all three sites, but it seems to be most salient among Latino immigrants in New York, of whom over two-thirds (19 out of 28) reported not receiving benefits because service providers paradoxically discriminated against individuals seeking benefits. In comparison, 13 out of the 26 respondents in Madrid and 11 out of the 24 respondents in London reported a similar experience. While the design of our study does not allow to infer statistically significant results or to generalize to other ethnic groups, our results may be indicative of a trend that would be worth exploring in subsequent analyses. As such, Ana's experience exemplifies the type of encounters that the majority of the respondents in this study faced (43 out of 78). The interviews revealed that secondary NTU is largely caused by social workers who were routinely perceived by Latino immigrants to adopt a moralizing tone when interacting with potential recipients, commending them sometimes explicitly to pull themselves up from their own bootstraps, instead of helping them claim the benefits for which they are eligible. Claimants were also frequently admonished for being supposedly "lazy" or "worthless", and are told that they should "just get a job". This attitude ignores extensive research that shows that most welfare beneficiaries only see welfare benefits as a last resort and would rather be able to work instead of depending on them (Jo 2013).

3 Translated from Spanish by the author. 
While perceived prejudice against welfare recipients was more prevalent in the United States among the respondents that were interviewed, it was also found in London and Madrid, as several respondents also reported feeling belittled and discriminated against due to their seemingly low socio-economic status. This would take the form of a social worker mocking their aspirations or a dismissing their qualifications for instance. While the number of social providers who exhibit prejudice against beneficiaries seems relatively low based on the interviews conducted, it is still significant and seems to disproportionately affect the lives of the individuals who interacted with them, as the potential recipients who may lose several years of entitlements are predominantly vulnerable individuals. Additionally, not receiving the benefits they are eligible to get further hinders their successful integration and upward social mobility. Even if this type of prejudice is not specifically targeted at Latino immigrants, it still affects them more than natives, due to the lack of resources (social capital or financial assets) at their disposal.

\subsection{Prejudice against Immigrants}

Another reason brought to light by the interviews as a reason preventing them from accessing social benefits for which they are entitled (e.g. secondary NTU) is the perceived prejudice toward immigrants on the part of social workers. This is illustrated by the story of Eduardo, a 39-year-old Chilean immigrant living in London, who tried to enroll for unemployment benefits in 2019 after he lost his job in a restaurant. Eduardo had been legally living in the United Kingdom for over 10 years and began working as a dishwasher in a restaurant. He progressively worked his way up and eventually became the general manager of one of the takeout outlets that the chain had been opening in recent years. However, due to the poor performances of the company, he was subsequently let go. He explains that after he filed an online application to receive a jobseeker allowance, he was invited to an interview in a job center. He describes his interactions with the caseworker negatively:

Well, it did not end well just like it did not start well. (...)[At the second appointment] she told me that I was lying and that I had money saved somewhere, because she said we [immigrants] could not be trusted. I told her that I was not lying, but she was very rude and she said that I could not get benefits anyway because I did not apply to enough jobs. I don't understand, I applied for a lot, but she just rushed to kick me out and she did not let me explain. (...) she said that I am not a citizen, so I don't get the same rights. Well, I have been here long enough to know that I qualify, I told her that and she asked if in my country, I could get benefits and that I should go back'.

Eduardo's experience at the job center was particularly stressful to him, and he describes each visit as a fight. After his initial interview, he started receiving benefits

$4 \quad$ Translated from Spanish by the author. 
but then explained that the payments stopped without warning. After he filed a complaint, his benefits resumed, but he claims that the caseworker makes unreasonable demands, such as proving that he has been applying to several dozens of jobs each week. He explains that the feelings of humiliation that he experienced there upset him. When asked if he had seen the caseworker interact with other jobseekers in the same way, he replied that he had the opportunity to see her deal with other people while he was waiting and that she seemed "a lot nicer", and "more decent" to British people. According to him, she is condescending and disrespectful toward him because he is an immigrant and she is biased toward them. During his six-month unemployment period, Eduardo's benefits were cut several times. He eventually found another job and stopped receiving benefits. He explained his sheer sense of relief when he became "independent" again and said that his interactions with the caseworker were one of the worse experiences he had experienced since moving to the country. He missed several weeks' worth of benefits and struggled to both financially and emotionally. He self-esteem had been damaged and he believes that this experience delayed his finding a new job.

Eduardo's experience shows that despite having contributed National Insurance for many years, he was not able to obtain the full benefits he was entitled to receive. Based on Eduardo's account, the social worker seemed to cut his unemployment benefits because of her belief that immigrants are essentially trying to abuse the system and collect benefits.

As exemplified by Eduardo, a significant number of respondents (58 out of 78) reported being denied public benefits because they believe a social worker deliberately chose to exclude them from the program for being immigrants. The respondents might appear to have internalized the notion that immigrants are perceived as abusing social benefits and even sometimes accused of relocating primarily to benefit from the supposed generosity of their host country. This welfare magnet theory has been debunked by research (Bruckmeier and Wiemers 2017), but studies are still showing extensive prejudice against non-natives beneficiaries of public services (Hainmueller and Hopkins 2014; Achiume 2014; McLaren 2015). This perception is sometimes accentuated by the media and politicians, who may condone or even promote such rhetoric, as exemplified in some of the speeches by Former British Prime Minister David Cameron and United States President Donald Trump (Leruth and TaylorGooby 2019). Caseworkers might feel empowered to act on their feelings and use their discretionary prerogatives to wrongfully deny certain benefits to immigrants, especially when there is little administrative oversight. Even though our study design does not allow to generalize across cities or immigrant group, the trend among our sample suggests that such cases were mostly found in London, where 20 out of 24 respondents reported being denied public assistance because they were immigrants.

Contrary to Ana's experience, Eduardo's negative encounters with the caseworker was not perceived to be primarily due to his low socio-economic status. He 
witnessed the caseworker interact in a much friendlier way with non-immigrant jobseekers. His perceived negative interactions with the social worker seems to counter the purpose of the social benefits, as, paradoxically, the job center seems to have delayed his finding a new job. His experience was not unique, and respondents from all three cities reported similar situations (18 out of 26 in Madrid and 20 out of 28 in New York City). However, in our sample, the occurrence among the sample was more frequent in London, where 4 out of every 5 respondents who had reported secondary NTU stated having been incorrectly refused benefits on the grounds of being an immigrant. In comparison, in New York and in Madrid, slightly more than half of the respondents reported secondary NTU due to the prejudice associated with being an immigrant. Our results may be explained by the increased anti-immigrant sentiments in the United Kingdom (Byrne et al. 2020), coupled with ever more restrictive welfare policies and a prevalent culture of individual responsibility. The literature has previously pointed to the correlation between the type of welfare state and attitudes towards migrants, showing that the more comprehensive the welfare state is, the more tolerant natives are of immigrants (Crepaz and Damron 2009). In our case, the shrinking welfare state in the United Kingdom might cause a hostile environment for immigrants, notably in their interactions with caseworkers. Further, it is also worth noting that because these categories are not mutually exclusive, Latino immigrants may report secondary NTU for more than one reason. While it is not possible to generalize due to our sample size, this would be worth exploring in subsequent studies in order to see if this can further be replicated with other immigrant groups as well.

\subsection{Prejudice Due to Skin Color}

Finally, a third factor identified in the secondary NTU of the respondents relates to the perceived prejudice from social workers that the respondents experienced due to their ethno-racial characteristics. This is the case of Bianca, a 31-year-old immigrant from Ecuador who moved to Madrid in 2014 with her husband who had been transferred to Madrid by his company. Prior to moving to Madrid, she worked as a legal advisor for a clothing company and after she relocated to Madrid, she tried to obtain an equivalency for her diploma to be able to obtain a similar position in Spain. However, she encountered many obstacles and settled for a sales position at the Corte Ingles. She began working there in September 2015 and soon thereafter she had her first child. She was unaware of the specific rules regarding maternity pay, and that in order to qualify for maternity pay, because she was over 26 years-old, she had to have worked for a total of 180 days within the 7 years before the birth of her child. Soon after her son was born, she visited the Social Security office to claim maternity benefits. She explains that the social workers she met during the process denied her claim. It is only after she had her second child that she realized that she had wrongfully been denied maternity pay following the 
birth of her first child. She remembers the first encounter she had with the social worker as particularly negative:

Now I realize that they did not give it [maternity benefits] to me, that they discriminated me. (...) Then it was my turn and the woman [caseworker] asked me to sanitize my hands. She said that people like me [darked-shinned] have a lot of germs. (...) Well, it has happened before, what it is, is that they tell you that black people they have a lot of germs, that we are dirty. I am dark, I get really dark in the sun, look at me [laughs] I think we bother them. (...) After I gave her all the documents, she asked me a lot of questions, like she wanted to make sure I was really who I am (...) she said that we [colored people] can fraud easier, because we look alike. (...) they are so racist that they cannot hide that they don't want to deal with you. (...). She wanted me to go, she was not comfortable with them there (...) because of my skin color. She was worried I would make her Black too [laughs]'.

Bianca prefers to laugh about it and downplays the impact that this encounter had on her and on her family. In Bianca's case, the social worker did not hide her prejudice against people of color which she supposes led to her being denied the maternity pay that she was supposed to receive. This experience affected her to the point that she did not want to return there, and be confronted to a similar situation, for her second pregnancy. Until her husband suggested to file the application online, she was willing to forgo her rights to maternity benefit.

The existing literature shows that visible minorities often experience stigmatizing racial stereotypes when accessing health care, which leads to inequalities and negatively affects their access to and use of care (Goodman et al. 2017). This was confirmed in the interviews, as 45 out of 78 respondents reported instances of discrimination based on their ethnicity, which they think led to them being denied rights for which they qualified (21 in Madrid, 16 in London and 17 in New York City).

The literature has extensively documented the negative effects that racism can have on the health of individuals (Goodman, et al. 2017). Experiences of discrimination or dismissal on the part of service providers often results in disengagement from care or delay in care (Goodman et al. 2017). This study further shows that it can also affect the socio-economic wellbeing of individuals, and further accentuate inequalities, by refusing them social benefits they are eligible to receive. This experience is not specific to Latino immigrants, and may also affect individuals who were born in the country and are citizens. Even though it appeared to be more salient in Madrid, respondents in London and New York also reported such experiences of discrimination based on their ethnicity. While our sample size and study design do not allow for a generalization across cities, this trend appears as counter-intuitive. Indeed, a recent comparative study on discrimination among Latinos in Spain

5 Translated from Spanish by the author. 
and the United States showed that due to their proximity in terms of culture and language, Latinos experience less discrimination in Spain than in the United States (Yemane and Fernandez-Reino 2019). However, other studies seem to better align with our findings, as they showed that the recent transformation of Spain into a new immigrant destination has been accompanied by the resurgence of race as the main primary explanation for discrimination among non-European immigrants in the country (Flores 2015), thereby potentially explaining the relatively high number of respondents reporting instances of prejudice based on their skin color.

\section{Conclusion}

In his seminal work, Kevin Johnson draws on intersectionality theory to show that, in the United States, "the negative impact of immigration status is compounded by the marginalizing effects of the ethnicity, class and gender of the affected immigrant community", thereby making it "inherently difficult for the interests of immigrants (...) to be vindicated by the political process" $(2009,1575)$. The present study extends the work conducted by Johnson by showing that Latino immigrants face multiple overlapping obstacles preventing them from benefiting from public benefits for which they are eligible.

Despite efforts by immigrants to access social benefits, cumulative levels of perceived prejudice on the part of service providers hampers their attempts. This study also shows that these findings hold true in all three sites, albeit with slight differences. In New York City, social workers' bias seems to be primarily due to immigration status and social class, including those who rely on government's handouts and those who were pejoratively called "welfare queens" (Foster 2008). In Madrid and London, the results indicate that prejudice is higher against visible minorities and immigrants respectively, and less so against those who use social benefits due to their precarious financial situation. This may be due to varying cultural biases or differing perception of this particular group of immigrants in these three cities that would be worth exploring in subsequent studies. Interestingly, we did not find variation along gender lines. ${ }^{6}$

Based on this analysis, secondary NTU may be attributed to the discretionary powers conferred to social workers play a large role in secondary NTU for Latino immigrants. Even though there has been "a decisive power shift in public services away from practitioners' discretion and towards a practice defined by guidelines and procedures" (Jessen and Tufte 2014, 270), street-level bureaucrats and social service providers continue to hold a great level of discretionary powers (Evans 2016).

6 Our sample was predominantly composed of women (almost 2/3), which might explain why a systematic gender analysis did not yield any significant difference between male and female respondents. 


\section{References}

Achiume, E. Tendayi. 2014. Beyond Prejudice: Structural Xenophobic Discrimination Against Refugees. Georgetown Journal of International Law 45(2): 323-382.

Arango, Luis, Dolores Mata, and Nataly Obando. 2015. Echoes of the Crises in Spain and US in the Colombian Labor Market: A Differences-in-Differences Approach. SERIEs 6(4): 441-477.

Arendt, Florient and Narin Karadas. 2019. Ethnic Concordance in Patient-Physician Communication: Experimental Evidence from Germany. Journal of Health Communication 24(1): 1-8.

Ayón, Cecilia. 2015. Economic, Social and Health Effects of Discrimination on Latino Immigrant Families. Migration Policy Institute: Washing DC. http://www.migrationpolicy.org/research/ economic-social-and-health-effects-discriminationlatino-immigrant-families.

Bargain, Olivier, Herwig Immervoll, and Heikki Viitamäki. 2012. No Claim, No Pain. Measuring the Non-Take-Up of Social Assistance Using Register Data. The Journal of Economic Inequality 10(3): 375-395.

Blix, Marten. 2018. Digitalization, Immigration and the Welfare State New Thinking in Political Economy Series Research Institute of Industrial Economics. Sweden Publication.

Bourgois, Philippe and Jeff Schonberg. 2009. Righteous Dopefiend. University of California Press.

Brodkin, Evelyn. and Malay Majmundar. 2010. Administrative Exclusion: Organizations and the Hidden Costs of Welfare Claiming. Journal of Public Administration Research and Theory 20(4): 827-848.

Bruckmeier, Kerstin and Jürgen Wiemers. 2017. Differences in Welfare Take-Up Between Immigrants and Natives - a Microsimulation Study. International Journal of Manpower 38(2): 226-241.

Byrne, Bridget, Claire Alexander, Omar Khan, James Nazro, and William Shankley (eds.). 2020. Ethnicity and Race in the UK: State of the Nation. Bristol, UK; Chicago, IL, USA: Bristol University Press

Calderon, Jose. 1992. Hispanic and Latino: The Viability of Categories for Panethnic Unity. Latin American Perspectives 19(4): 37-44.

Crepaz, Markus and Regan Damron. 2009. Constructing Tolerance: How the Welfare State Shapes Attitudes About Immigrants. Comparative Political Studies 42(3): 437-463.

Currie, Janet. 2004. The Take Up of Social Benefits. National Bureau of Economic Research. pp. 80-148 in Auerbach, Alan, David Card, and John Quigley (eds), Public policy and the income distribution, New York: Russel Sage Foundation, 2006.

Dragos, Radu, Maria Hudson and Joan Phillips. 2010. Migrant Workers' Interactions with Welfare Benefits: A Review of Recent Evidence and its Relevance for the Tax Credits System. HMRC Research Report 115.

Ebbinghaus, Bernhard. 2012. Comparing Welfare State Regimes: Are Typologies an Ideal or Realistic Strategy? European Social Policy Analysis Network. ESPAnet Conference.

Esping-Andersen, Gøsta. 1990. The Three Worlds of Welfare Capitalism. Princeton, N.J: Princeton University Press.

Eurofund. 2015. Access to Social Benefits: Reducing Non-Take-Up. Publications office of the European Union, Luxembourg. https://www.eurofound.europa.eu/sites/default/files/ef_publication/ field_ef_document/ef1536en.pdf.

Evans, Tony. 2016. Professional Discretion in Welfare Services: Beyond Street-Level Bureaucracy. New York: Routledge.

Finn, Daniel and Jo Goodship. 2014. Take-Up of Benefits and Poverty: An Evidence and Policy Review. Centre for Economic and Social Inclusion. London.

Foster, Carly. 2008. The Welfare Queen: Race, Gender, Class, and Public Opinion. Race, Gender \& Class 15(3/4): 162-179. 
Fuchs, Michael, Katrin Gasior, Tamara Premrov, Katarina Hollan, and Anette Scoppetta. 2020. Falling through the Social Safety Net? Analysing Non-Take-up of Minimum Income Benefit and Monetary Social Assistance in Austria. Social Policy \& Administration 54: 827-843.

Flores, René. 2015. The Resurgence of Race in Spain: Perceptions of Discrimination Among Immigrants. Social Forces 94(1): 237-269.

Glick Schiller, Nina, Ayșe Çağlar, and Thaddeus C. Guldbrandsen. 2006. Beyond the Ethnic Lens: Locality, Globality, and Born-Again Incorporation. American Ethnologist 33(4): 612-633.

Goodman, Ashley, Kim Fleming, Nicole Markwick, Louise Lagimodiere, and Thomas Kerr. 2017. "They Treated Me Like Crap And I Know It Was Because I Was Native": The Healthcare Experiences of Aboriginal Peoples Living in Vancouver's Inner City. Social Science and Medicine 17: 87-94.

Grosios, Konstantina, Peter Gahan, and Jane Burbidge. 2010. Overview of Healthcare in the UK. The EPMA journal 1(4): 529-534.

Hainmueller, Jens and Daniel Hopkins. 2014. Public Attitudes Toward Immigration. Annual Review of Political Science 17(1): 225-249.

Harris, Jennifer. 2020. The Digitization of Advice and Welfare Benefits Services: Re-Imagining the Homeless User. Housing Studies 35(1): 143-162.

Hooijer, Gerda and Georg Picot. 2015. European Welfare States and Migrant Poverty: The Institutional Determinants of Disadvantage. Comparative Political Studies 48(14): 1879-1904.

Isakjee, Arshad. 2017. Welfare State Regimes: A Literature Review', IRiS Working Paper Series, 18/2017 (UPWEB Working Paper Series, No. 5/2017) Birmingham: Institute for Research into Superdiversity.

Jessen, Jorunn and Per A. Tufte. 2014. Discretionary Decision-Making in a Changing Context of Activation Policies and Welfare Reforms. Journal of Social Policy 43(2): 269-288.

Jo, Yongmie. 2013. Psycho-Social Dimensions of Poverty: When Poverty Becomes Shameful. Critical Social Policy 33: 514-531.

Johnson, Kevin. 2009. The Intersection of Race and Class in U.S. Immigration Law and Enforcement. Law and Contemporary Problems 72(4): 1-35.

Kayser, Hilke and Joachim Frick. 2000. Take It or Leave It:(Non-)Take-Up Behavior of Social Assistance in Germany. Discussion Paper No. 210. German Institute for Economic Research (DIW).

Leruth, Benjamin and Peter Taylor-Gooby. 2019. Does Political Discourse Matter? Comparing Party Positions and Public Attitudes on Immigration in England. Politics 39(2): 154-169.

Lipsky, Michael. 1980. Street Level Bureaucracy; Dilemmas of the Individual in Public Services. New York: Russell Sage Foundation.

Lo, Ming-Cheng and Roxana Bahar. 2013. Resisting the Colonization of the Lifeworld? Immigrant Patients' Experiences with Co-ethnic Healthcare Workers. Social Science \& Medicine 87: 68-76.

Lott, Bernice and Heather Bullock. 2007. Psychology and Economic Injustice: Personal, Professional, and Political Intersections. American Psychological Association. The book is 190 pages

Mallet, Marie and Johanna Pinto-Coelho. 2018. Investigating Intra-Ethnic Divisions Among Latino Immigrants in Miami, Florida. Latino Studies 16: 91-112.

Mar-Molinero, Clare 2002. The Politics of Language in the Spanish-Speaking World: From Colonization to Globalization. London and New York: Routledge.

Mazet, Pierre. 2014. Analysis of the Non-Take-Up of Benefits: A Public Policy Assessment Tool. Service de lutte contre la pauvreté, la précarité et l'exclusion sociale, Bruxelles, Belgium.

Mcllwaine, Cathy. 2015 Legal Latins: Creating Webs and Practices of Immigration Status among Latin American Migrants in London. Journal of Ethnic and Migration Studies 41(3): 493-511.

McLaren, Lauren. 2015. Immigration and Perceptions of National Political Systems in Europe. Oxford: Oxford University Press. 
Morales, Laura and Alfonso Echazarra. 2013. Will We All Hunker Down? The Impact of Immigration and Diversity on Local Communities in Spain. Journal of Elections. Public Opinion \& Parties 23(3): 343-366.

Moreno Fuentes, Francisco and Maria Bruquetas Callejo. 2011. Immigration and the Welfare State in Spain. Barcelona: Coleccion Estudios Sociales. LaCaixa.

Petropoulos, Georgias, Scott Marcus, Nicolas Moës, and Enrico Bergamini. 2019. Digitalization and European Welfare States. Bruegel Blueprint Series 30.

Porter, Lakeisha. 2006. Illegal Immigrants Should Not Receive Social Services. International Social Science Review 81(1/2): 66-72.

Reijnders, Mark, Jelmer Schalk, and Trui Steen. 2018. Services Wanted? Understanding the Non-TakeUp of Social Support at the Local Level. VOLUNTAS 29(6): 1360-1374.

Reitz, Jeffrey G., Patrick Simon, and Emily Laxer. 2017. Muslims' Social Inclusion and Exclusion in France, Québec, and Canada: Does National Context Matter? Journal of Ethnic and Migration Studies 43(15): 2473-2498.

Riphahn, Regina, Monika Sander, and Christoph Wunder. 2013. The Welfare Use of Immigrants and Natives in Germany: The Case of Turkish Immigrants. International Journal of Manpower 34(1): $70-82$.

Römer, Friederike. 2017. Generous to All or 'Insiders Only'? The Relationship between Welfare State Generosity and Immigrant Welfare Rights. Journal of European Social Policy 27(2): 173-196.

Sainsbury, Diane. 2006. Immigrants' Social Rights in Comparative Perspective: Welfare Regimes, Forms in Immigration and Immigration Policy Regimes. Journal of European Social Policy 16(3): 229-244.

Sainsbury, Diane. 2012. Welfare States and Immigrant Rights: The Politics of Inclusion and Exclusion: Oxford University Press.

Scheibelhofer, Elisabeth, and Clara Holzinger. 2018. 'Damn It, I Am a Miserable Eastern European in the Eyes of the Administrator': EU Migrants' Experiences with (Transnational) Social Security. Social Inclusion 6(3): 201-209.

Shi, Leiyu, Gregory Stevens, Lydie Lebrun, Pegah Faed, and Jenna Tsai. 2008. Enhancing the Measurement of Health Disparities for Vulnerable Populations. Journal of public health management and practice 14: 45-52.

Smith, Laura. 2010. Multicultural Foundations of Psychology and Counseling Series. Psychology, Poverty, and the Rnd of Social Exclusion: Putting our Practice to Work. New York: Teachers College Press.

United Nations. 2017. International Migration Report 9. New York: United Nations.

U.S. Census Bureau. 2015. Population Estimates, https://www.census.gov/acs/www/data/data-tablesand-tools/data-profiles/2015/ (27.06.2020).

USCIS. 2018. Final Rule on Public Charge Ground of Inadmissibility. www.uscis.gov/archive/archive-news/final-rule-public-charge-ground-inadmissibility (27.06.2020).

van Oorschot, Wim. 1991. Non-Take-Up of Social Security Benefits in Europe. Journal of European Social Policy 1(1): 15-30.

van Oorschot, Wim. 1995. Realizing Rights: A Multi-Level Approach to Non-take-up of Means-tested Benefits. Aldershot: Avebury.

van Oorschot, Wim. 1996. Modelling Non-Take-Up: The Interactive Model of Multi-Level Influences and the Dynamic Model of Benefit Receipt. In New Perspectives on the Non-take-up of Social Security Benefits, edited by Wim van Oorschot. Tilburg: Tilburg University Press.

Warin, Philippe. 2008. Le non-recours par désintérêt: la possibilité d'un «vivre hors droits». Vie sociale 1(1): 9-19.

Warin, Philippe. 2014. What Is the Non-Take-Up of Social Benefits. Books and Ideas 9: 1-12. 
Weinberg, Merlinda. 2010. The Social Construction of Social Work Ethics: Politicizing and Broadening the Lens. Journal of Progressive Human Services 21(1): 32-44.

Yemane, Ruta and Mariña Fernández-Reino. 2019. Latinos in the United States and in Spain: the Impact of Ethnic Group Stereotypes on Labour Market Outcomes. Journal of Ethnic and Migration Studies 47(6): 1240-1260. Doi: 10.1080/1369183X.2019.1622806. 